\title{
The First Arab-Islamic Conference
}

\author{
5-7 Jumādā al Ûlā 1415 / 10-12 October 1994 \\ Beirut, Lebanon
}

This conference has been in preparation for almost thirty months. The reason for this rather long (by Middle Eastern standards) gestation period was the unprecedented nature of the conference, difficulties of selecting participants and finding a safe and available location.

Since the early 1950s, Arab nationalist and Islamic relations have been passing through very turbulent periods. The secularization of Arabism and the rise of Arab nationalists to power in many Arab countries led to frequent and bloody confrontations between the two sides over power and legitimacy of the state. However, during the last two decades, Arab regimes have become somewhat less ideological and more tyrannical; coercive means rather than persuasion has been widely deployed to preserve the status quo. As a result, many Arab nationalist intellectuals, activists, and public leaders have dissociated themselves from the ruling elites and moved to establish independent Arab nationalist formulae, research centers, and groupings. Parallel to this turn was the spectacular rise of Islamic political forces in almost all part of the Arab world, a development that could not be ignored by the Arab nationalists.

One of the main results of the Gulf War was a growing sense of rapprochement between the nationalist and Islamist camps. In 1993 a group representing the two sides (including Rāshid al Ghannūshī, Khayr al Din Hạasib, Muḥammad Șidq̄i al Dajānī, 'Isām Nu'mān, and a representative of Hasan al Turabī) agreed to hold an Arab-Islamic conference to mark the era of reconciliation and set an agenda for both camps. Meeting in London, they agreed to invite 100 representatives (approximately 50 from each camp), nominated a preparatory committee, and named most of the would-be participants. For many months afterwards, the preparatory committee worked to surmount the many obstacles which, to a certain extent, nearly undermined the enterprise. Eventually, after the Muslim Brotherhood of Egypt had agreed to participate, the Arab nationalists had agreed to drop their insistence on inviting members of the Sudanese opposition, and the Lebanese government (as well as the Syrians) had given permission to hold the conference in Beirut, it was decided to convene the conference on 12 October 1994.

Almost 100 participants attended the conference, divided into three main categories: representatives of Islamic organizations, those of nationalist parties, and independents of different inclinations. No typical Arab Marxists were invited. Among the more prominent attendees were Yūṣuf 
al Qaraḍāwī, Rāshid al Ghannūshī, 'Isām al Ariān (official representative of Egypt's Ikhwān al Musliminn), Salim al 'Awwā, Fahmī Huwaydì, Munīr Shafiq, Mūṣā Abū Marzūq, Fathị Shikākì (the latter two being from HAMAS and Jihad of Palestine), Șidqī al Dajānī, Khayr al Din Ḥasib, Sayyid M. H. Faḍl Allāh, M. Mahdı̄ Shams al Dinn, Muhammad 'Amārah, and Yāsīn 'Umar al Imām.

Al Dajānī, who is viewed as an acceptable figure from both sides, gave the opening speech. He was eloquent, impressive, and comprehensive in his survey of the state of the ummah within the international context. Following his speech, senior ulama and distinguished participants were given relatively adequate time to make their points, and the rest of the time was allocated into ten minutes for each speaker. The time limitations and nature of the gathering, being the first of its kind, leaned toward an emphasis on the political, rather than the intellectual, dimension of the Arab-Islamic question. However, the majority of the participants were able to express their opinions on the urgent need for Arab nationalists and their Islamist counterparts to reconcile their differences and open a new era in modern Arab political and intellectual life. This point was stressed again in the concluding statement of the conference.

An objective observer could discern easily that, while recognizing Islam as the frame of reference of Arab societies and a clear separation between Arabism and secularism were nonnegotiable points for the Islamists, diehard Arab nationalists of the old generation were still trying to play the game of redefining secularism and socialism. An undercurrent of apprehension on the part of the nationalist side of the rise and power of political Islam and the ambiguous Islamic discourse (and practice as in Iran and Sudan) on democracy, pluralism, and the peaceful alteration of government was also apparent. All in all, what is important was the atmosphere of the conference, where members of the hitherto antagonist camps were able to get out of their trenches, sit face to face, exchange ideas, and conduct a highly civilized dialogue.

The concluding statement was heavily loaded with a defiant antiIsraeli message. It underlined the Arab determination to defend their cultural-political independence and called for a pan-Arab reconciliation. The statement condemned the sieges imposed on Iraq, Libya, and Sudan and called for the release of Kuwaiti prisoners in Iraq. More importantly, there was an agreement to turn the conference into a permanent forum that will meet every two years and to elect a follow-up committee of thirty-six members from both camps that also includes two women. Al Dajānī, in a moment of genuine consensus, was elected a coordinator for the conference (in effect a leader of the follow-up committee).

Basheer Nafi

AJISS Associate Editor Herndon, Virginia 